\title{
Minimum Cell Density
}

National Cancer Institute

\section{Source}

National Cancer Institute. Minimum Cell Density. NCI Thesaurus. Code C120711.

The minimum value in a range of values that describe cell density. 